\title{
EN MEMORIA DE JOSÉ ROMANO MUÑOZ
}

El 14 de diciembre de 1967 murió José Romano Muñoz. Tenía setenta y siete años de edad.

Doctor en Filosofía y catedrático de la Universidad Nacional, Romano Muñoz llevó al cabo meritoria labor de difusión cultural. Fue Director General de Enseñanza Superior e Investigación Científica de la Secretaría de Educación Pública, presidente de la Academia de Educación, miembro del Centro de Estudios Filosóficos de la Universidad Nacional durante el año de 1947. Representó a México ante el comité de acción cultural de la OEA y fungió como representante de la comisión nacional de la Unesco en México. Recibió condecoraciones de Japón, Haití, Ecuador y Alemania. En 1952, Francia le concedió las Palmas Académicas. Entre sus principales obras sobresalen El secreto del bien y del mal y Hacia una filosofia existencial.

Como Samuel Ramos, José Romano Muñoz perteneció a la generación de los "Contemporáneos". Fue discípulo de Antonio Caso, pero no se afilió totalmente a las ideas de su maestro; en cambio, propagó en México ideas de Ortega y Gasset. En una época en la que imperaba el bergsonismo que Caso había introducido en México, Romano Muñoz estudió a los filósofos alemanes e italianos y a los pensadores de Norte y Sudamérica. Más adelante se sumó al movimiento fenomenológico, principalmente a Scheler y a Hartmann. Ambos filósofos están presentes en El secreto del bien y del mal.

El secreto del bien $y$ del mal ha servido a varias generaciones. Apareció por primera vez en 1938. Poco más tarde, la Escuela Nacional Preparatoria lo adoptó como libro de texto. En 1961 la obra llegó a su quinta edición. Esta última no lleva cambios sustanciales. Desde el principio, el autor se adhirió a la ética valorativa y al apriorismo axiológico y concibió a los valores como datos inmediatos de la intencionalidad emocional. En este sentido, analizó los problemas de la esencia y del origen del acto moral, la obligatoriedad y la valoración moral y también la realización de los valores: todo esto dentro de una posición crítica frente al empirismo y el determinismo.

Hacia una filosofía existencial fue publicada en 1953. Aquí el autor se declara existencialista, "si por existencialismo se entiende lisa y llanamente una corriente de pensamiento que hace del existir humano individual el punto de partida del filosofar". Pero el existencialismo de Romano Muñoz quiere "estar al margen de la nada, de la muerte y dé la náusea metafísica". Por eso no se acoge a los lineamientos principales de Heidegger y Sartre; más aún, la crítica, y el deseo de criticarlos, fue uno de los motivos que lo llevó a escribir Hacia una filosofía existencial. Heidegger y Sartre, en el sentir del autor, "despojan a la vida humana de toda finalidad, de toda razón de ser, de todo sentido". Contra ellos, Romano Muñoz quiere dejar paso a la esperanza "como único asidero del ser 
para su angustia". Sin embargo, no se acerca precisamente a Gabriel Marcel; se diría que, en muchos sentidos, se deja influir por Ortega y Gasset.

Romano Muñoz dedicó gran parte de su vida a la labor docente. Desde 1918, fue profesor de lógica, ética, psicología y civismo en la Escuela Nacional Preparatoria y, durante algunos años contados a partir de 1945, profesor de ética en la Facultad de Filosofía y Letras de la Universidad Nacional. En 1965, por jubilación, renunció a sus cátedras. A su muerte ocupaba el cargo de asesor técnico del secretario de Educación Pública y la vicepresidencia de la Sociedad Mexicana de Filosofía. Dejó en preparación tres obras: Iniciación a la cultura, Tratado de lógica aplicada y El sentido espiritual de la vida.

Rosa Krauze 